\title{
Språket som hydra - några tankar om språkvetenskapliga analysperspektiv
}

\author{
Jan Svensson \\ Den moderna språkvetenskapen har förgrenats i ett mycket stort \\ antal traditioner med varierande vetenskapsteoretiska och meto- \\ diska utgångspunkter. I artikeln diskuteras tre olika områden med \\ fokus på satsgrammatik, text respektive språkhandlingar. Likhe- \\ ter och skillnader lyfts fram, framför allt med avseende på rela- \\ tionen till begreppen system och bruk. En viktig skillnad mel- \\ lan de olika områdena är deras respektive kvalificeringskriterier, \\ grammatikalitet, koherens och "lyckadhet". Områdena skiljer sig \\ också åt vad gäller möjligheterna till systembaserade generalise- \\ ringar respektive nödvändigheten av bruksbaserade tolkningar. \\ Undersökningar av satsgrammatiska fenomen klarar sig ganska \\ bra utan explicita redogörelser för autentiskt bruk, medan under- \\ sökningar av språkhandlingar är helt beroende av dem, åtmins- \\ tone då undersökningarna avser annat än tillrättalagda exempel. \\ I artikeln diskuteras också möjligheten att förstå komplexa texter \\ som språkhandlingar.
}

Den moderna språkforskningen har förgrenat sig i ett nästan oöverskådligt antal inriktningar och angreppssätt, av vilka somliga fokuserar på de grammatiska systemen, ofta med tonvikt på syntaxen, andra på förutsättningarna för att bygga sammanhängande texter eller på de sociala förutsättningarna för språkanvändning, osv. Inom varje område har de efterhand utökade insikterna lett till en avsevärd specialisering, vilket i sin tur medfört att kommunikationen mellan forskare från de olika områdena försvåras eller i värsta fall blir obefintlig. I de flesta fall blir denna ordning inte problematisk, utan respektive verksamhet får kraft just av de tydligt definierade perspektiven. Men ibland uppstår ändå behov av att låta olika analys- och beskrivningsperspektiv brytas mot varandra, något som jag vill göra i den här artikeln. Jag har inte am- 
bitionen att skapa någon heltäckande ordning för perspektivöverskridande analys, men jag vill diskutera ett antal fenomen som uppträder i skärningspunkten mellan den satsgrammatiska analysen, textanalysen och språkhandlingsanalysen. Jag vill vrida på en del av de begrepp som används inom de olika traditionerna och se vilka beröringspunkter som kan finnas mellan dem. I det sammanhanget är jag också intresserad av de vetenskapsteoretiska positionerna. Det blir en del begreppsexercis och upprepande av självklarheter, men det är nog nödvändigt i ett läge där termer och begrepp hela tiden förmeras och skiftar gestalt.

Den viktigaste skiljelinjen i de resonemang som förs i det följande är distinktionen mellan 'system' och 'bruk'. Många av de teoretiska kontroverser som utspelats under de senaste decennierna bottnar i skiljaktigheter om var fokus för den språkliga analysen bör ligga. Åtminstone sedan de Saussure har det varit möjligt att uppfatta språkforskningen som en verksamhet som har till uppgift att beskriva och eventuellt förklara det språkliga systemet och dess delar, oberoende av hur det används i den ena eller andra situationen. Denna hållning har lika länge utmanats av dem som menar att språk inte låter sig beskrivas annat än i sin sociala och historiska kontext. Från något slags ontologisk utgångspunkt är den sistnämnda hållningen den rimliga. Språket kan inte vara något utan sina brukare (jfr Gregersen 2006). Detta hindrar emellertid inte att man kan betrakta språket som om det vore ett system. Den abstrakta systembeskrivningen blir då en beskrivning av de resurser som står till språkbrukarnas förfogande. Och en sådan beskrivning kan utan problem förenas med eller bedrivas vid sidan av en beskrivning av språkbrukarnas användning av de tillgängliga resurserna. Den viktiga poängen är att det är frågan om olika slags beskrivningar, med olika forskningsfokus och med olika syften.

Distinktionen mellan system och bruk aktualiserar också distinktionen mellan det generella och det partikulära. Systembeskrivningar måste med nödvändighet ha generalitetsanspråk, antingen det rör sig om generella principer för det mänskliga språket eller generella beskrivningar av särspråkliga system. Sådana generella beskrivningar måste grunda sig på empiriska data som kan göras tillgängliga genom studium av faktiskt språkbruk (via introspektion, eliciteringsstudier eller korpusstudier), men forskningens fokus ligger på de principer som kan abstraheras fram av analysen. Då empirin i sig utgör forskningsfokus kan undersökningarna sägas vara partikulära. Detta gäller vare sig intresset 
riktas mot en enskild text eller mot olika slags etiketterade texttyper (se Svensson 2005).

Den övergripande frågan i det följande blir därför hur långt det är möjligt att pressa system- respektive bruksperspektiven i en analys av satsgrammatiken, texten eller språkhandlingarna, men denna övergripande fråga motiverar också en rad frågor om vilka generaliseringar som är möjliga inom respektive perspektiv. Eftersom de olika perspektiven hela tiden griper in i varandra kunde det ha varit motiverat att diskutera skärningspunkten mellan alla tre i ett sammanhang. För framställningens och överskådlighetens skull kommer jag emellertid att diskutera två perspektiv i taget, först satsgrammatik och text, därefter satsgrammatik och språkhandlingar och slutligen språkhandlingar och text. Därefter kommer jag i ett exemplifierande avsnitt att illustrera hur en analys som tar hänsyn till de olika perspektiven skulle kunna gå till och var gränserna för olika analyser går. I det avslutande avsnittet försöker jag föra samman en del av iakttagelserna.

\section{Satsgrammatik och text}

Med begreppet 'satsgrammatik' menar jag i det följande de fenomen som ägnades intresse i den traditionella grammatiken och som också har varit i fokus i strukturalistiska och generativa grammatiktraditioner. Intresset riktas mot de fenomen som beskrivs inom satsens ram, dvs. i första hand morfologiska och syntaktiska fenomen. Jag gör inget försök att problematisera begreppet här. Däremot kan det finnas skäl att stanna ett ögonblick vid begreppet 'text'. Begreppet är centralt i många analytiska sammanhang, men kan användas på flera olika sätt. En vanlig användning av begreppet är att ta fasta på den ursprungliga betydelsen 'väv' och låta termen "text" stå för sådana sammanhängande språkliga enheter som går utöver satsens ram. Den typ av frågor som då oftast ställs är sådana som har att göra med hur texter är ihopskruvade, vad det är som gör en text till en text. Dessa frågor är de dominerande i den textlingvistiska traditionen så som den utvecklades på 1970-talet (se t.ex. van Dijk 1972). Men termen "text" används ofta också för att beteckna det vi gör när vi använder språket. Det mest typiska området för denna användning är olika slags diskursanalytiska traditioner. I dessa traditioner hanteras förvisso språkliga enheter som går utöver satsens ram, men det är inte det förhållandet som genererar forskningsfrågorna. Intresset kan mycket väl vara riktat mot yttranden som bara består av en sats eller för den delen bara av ett enda ord. I den tidiga versionen 
av Norman Faircloughs diskursanalytiska program benämns metoden "Text oriented discourse analysis" (Fairclough 1992). (För en diskussion av skillnaderna mellan dessa båda textbegrepp se Svensson 2005.) En tredje användning, som nära ansluter till den andra, är den som aktualiserar fenomenet 'textvärde' (se Asdal m.fl. 2008). Här kopplas textbegreppet till någon typ av kvalitetsvärdering som utförs av (delar av) språkbrukskollektivet. En fjärde användning är den som aktualiseras i uttrycket "det utvidgade textbegreppet", där termen "text" kan användas som synonym till "semiotiskt tecken" (för en diskussion se Wendt 2009). I den fortsatta framställningen kommer jag att återknyta till de båda första användningarna av begreppet 'text'. Den tredje och fjärde användningen lämnas utanför just denna diskussion.

Låt oss för ett ögonblick inta systemperspektivet och fundera över satsgrammatiska begrepp som kan ha motsvarigheter på textnivån. Ett centralt begrepp i satsgrammatiken är 'grammatikalitet'. Begreppet kan definieras (eller operationaliseras) på många olika sätt, men det är under alla omständigheter avgörande för vilka konstruktioner som ska anses tillhöra systemet. Eller annorlunda uttryckt: som utgör en del av de tillgängliga resurserna. Det motsvarande begreppet på textnivån är rimligen 'koherens'. En språklig sekvens som med en eller annan metod bedöms vara koherent kan sägas vara en välformad text, på samma sätt som en ordsekvens som uppfattas som grammatisk kan vara en välformad sats eller fras (eller någon annan grammatisk konstruktion). Det går att invända mot resonemanget genom att hävda att vad som uppfattas som koherent är beroende av situationskontexten och därför inte låter sig avgöras på den systematiska nivån. Det är lätt att hitta exempel på svåra avgöranden om man vänder sig till öppna texttyper som poesi och annan skönlitteratur, där tolkning är ett integrerat led i läsningen. Motsvarande gäller emellertid också för många av de satsgrammatiska avgörandena. För att bara ta ett exempel: Möjligheterna till spetsställning av andra led än subjektet är ofta beroende av omgivande kontext och kan behöva backas upp av särskild prosodi etc., för att uppfattas som grammatiska.

Jag betraktar 'grammatikalitet' respektive 'koherens' som de viktigaste kvalificeringskriterierna för satser respektive texter, dvs. det är dessa begrepp som i första hand bestämmer om vi har med en sats respektive en text att göra. Man kan tänka sig andra begrepp som är viktiga vid bedömningen av det ena eller det andra. Det går till exempel att tala om 


\section{Språket som hydra}

satsers 'adekvathet', men då är man genast över i pragmatiska överväganden, som inte är avgörande för om vi har att göra med en sats eller inte. Det är också möjligt att tala om texter i termer av 'kohesion', dvs. de språkliga medel som används för att tydliggöra koherensen. I de flesta välformade texter samspelar dessa båda egenskaper, men det är frågan om koherens som är det avgörande. Vi kan tänka oss (även välfungerande) texter som har mycket sparsamt med kohesionsmarkörer, men vi kan inte rädda en osammanhängande text även om vi använder aldrig så många kohesionsmarkörer.

Lite svårare blir det om vi vill söka textuella motsvarigheter till de satsgrammatiska begreppen 'sats', 'fras' och 'satsdel'. Utgångspunkten är att motsvarigheten till 'sats' (eller kanske snarare 'huvudsats') är 'text'. Men är det möjligt och meningsfullt att försöka hitta motsvarigheter till de båda andra begreppen? Fraserna är ju satsernas byggstenar; det är av dem som vi med hjälp av de rekursiva principerna kan bygga upp mer eller mindre komplexa strukturer inom satsens ram. Ett bud på vad som skulle kunna vara de textuella motsvarigheterna är de av Adam (1992) föreslagna sekvensprototyperna (som också har kallats textaktiviteter och framställningsformer). Det finns ingen allmän samstämmighet om vilka sekvensprototyper som kan förekomma eller hur många de skulle vara, men det föreligger relativt stark konsensus om att de ska vara få, att de ska vara grundläggande och att de ska kunna kombineras på olika sätt för att skapa större sammanhängande enheter. Ledin (2000) urskiljer fem olika sekvenstyper, med var sina prototypiska utformningar. Den narrativa sekvensen består prototypiskt av introduktion eller sammanfattning, utgångssituation, komplikation, händelsekedja, upplösning, slutsituation samt avslutande evaluering eller sensmoral. Den deskriptiva sekvensen består av förankring, reformulering, aspektualisering, relation samt tematisering. Den argumentativa sekvensen består av tidigare tes, argument, inferensregler samt konklusion. Den explanativa sekvensen består av introduktion, problem, förklaring samt kommentar. Den instruerande sekvensen består av förutsättningar, transformation och resultat.

Ett problem med sekvensprototyperna/textaktiviteterna så som de beskrivs av Adam och Ledin är att de trots allt är tämligen komplexa. I vissa fall kan de få karaktär av genrekarakteristiker. Det vore enligt min mening angeläget att låta sekvensprototyperna (eller något liknande) utgöras av enklare, ännu mer grundläggande enheter med mycket enty- 


\section{Jan Svensson}

dig struktur. En möjlighet vore att laborera med s.k. processtyper, som i princip realiseras som satser, men som kan realiseras i ett begränsat antal kategorier.

En viktig dimension i det satsgrammatiska systemet är satsdelsfunktionerna. Det kan råda olika uppfattningar om hur satsdelarna ska definieras, hur många som ska urskiljas osv., men de är en ständigt återkommande beståndsdel i de syntaktiska beskrivningarna. Samstämmigheten om vilka satsdelar som ska urskiljas vid beskrivningen av ett visst språk är trots teoretiska meningsskiljaktigheter tämligen god. De grundläggande (i betydelsen 'ofta använda') kombinationerna är också ganska få (se Jörgensen 1976). Här är det emellertid betydligt svårare att finna några motsvarigheter i textbeskrivningen. Variationsmöjligheterna kan lätt förefalla oändliga. Någon generell motsvarighet till satsdelsbegreppet lär man inte hitta. Däremot kan man komma ett litet steg på vägen om man inte talar om texter generellt utan i stället om olika genrer.

Begreppet 'genre' är notoriskt svårhanterligt och har ett användningsområde som går långt utanför det som i vid mening kan betraktas som språkvetenskapens domäner. Det har använts för att beteckna de stora litterära framställningsformerna epik, lyrik och dramatik, liksom för underavdelningar inom epiken som roman och novell eller som beteckning för olika slags romaner som utvecklingsroman, historisk roman, underhållningsroman, deckare osv. Begreppet används också som beteckning för icke-språkliga uttrycksformer som film och musik. Men även inom den språkvetenskapliga textforskningen finns det många uppfattningar om hur begreppet 'genre' ska hanteras. Den tydligaste skiljelinjen går mellan en uppfattning av genre som något som konstitueras av de språkliga drag som texten uppvisar och en uppfattning av genre som en beteckning för olika typer av sociala processer (se Ledin \& Selander 2003). I de senaste decenniernas textforskning kan man nog säga att den senare uppfattningen har varit dominerande, dock inte alltid konsekvent genomförd. Ett intressant exempel på svårigheterna att låta det ena eller andra perspektivet vara avgörande är den tämligen aktuella framställningen i Martin \& Rose (2008). Inledningsvis definierar författarna genre som "staged, goal oriented social processes" och som ett förtydligande skriver de att detta i det systemfunktionalistiska perspektivet betyder att "genres are defined as recurrent configurations of meaning and that these recurrent configurations of meaning enact the social practices of a given culture" (Martin \& Rose 2008:6). I den empiriska 


\section{Språket som hydra}

analysen tillämpas emellertid i praktiken ett genrebegrepp som bygger på de språkliga drag som de undersökta texterna uppvisar. Författarna analyserar fram ett antal taxonomier där de ingående typerna skiljs från varandra på grundval av de språkliga drag som bygger upp dem.

Det som för mig framstår som det centrala i sammanhanget är konventionaliseringen. För att en genre ska uppstå måste det ske en konventionalisering både av den diskursiva praktiken (som den beskrivs av Fairclough 1992) och av den språkliga utformningen på textnivå. Konventionaliseringen gör det möjligt att peka ut prototypiska förekomster av texter inom en viss genre, dvs. texter som används i en kommunikativ situation enligt ett konventionaliserat mönster och som uppvisar drag som på motsvarande sätt är konventionaliserade. Det faktum att vi både kan ge en systembaserad beskrivning av prototypen och att vi kan återfinna den i autentiska situationer betyder emellertid inte att avvikelser i ena eller andra avseendet diskvalificerar en text från att tillhöra en viss genre. En skribent kan använda genrefrämmande språkdrag för att uppnå en viss effekt, och den konventionaliserade språkdragsuppsättningen kan givetvis förändras över tid. Det är också möjligt att rycka ut en genre ur sitt egentliga kommunikativa sammanhang om särskilda behov föreligger. Det tydligaste exemplet är olika former av skolskrivande, där elever förväntas skriva t.ex. nyhetsartiklar, insändare eller debattartiklar utan att de ingår i en sådan diskursiv praktik där detta är motiverat.

Oberoende av den principiella diskussionen om genrebegreppet kan man konstatera att texter som av olika skäl förs samman i etiketterade texttyper (Svensson 2005) ofta kan analyseras på ett sätt som ger en parallellitet till satsgrammatikens satsdelstopologi. Ett tidigt och ofta refererat exempel är van Dijks analys av nyhetstexter, vilka ju ofta följer starkt konventionaliserade mönster (van Dijk 1972; jfr. också Sandahl u.u.). Det finns ett ganska stort antal genrer som är hårt nischade och $\mathrm{i}$ vilka skribenternas möjligheter till kreativa lösningar är tämligen små; olika delar av den text som ska skrivas måste komma i en viss ordning och inga delar får utelämnas. I dessa fall kan man säga att vi har en parallellitet till de satsdelar som satsen är uppbyggd av. I det satsgrammatiska perspektivet kan vi identifiera fraserna och vi kan också ge en beskrivning av vilka grammatiska (syntaktiska) funktioner fraserna spelar. I det textuella perspektivet kan vi (kanske) identifiera de grundläggande textaktiviteterna och vi kan också ge beskrivningar av vilka 
textstrukturerande funktioner som textaktiviteterna har - partikulärt i en enskild text och mer generellt i olika genrer. Men då är vi också på väg att lämna systembeskrivningen. Vi kan inte göra generella beskrivningar för texter i allmänhet.

\section{Satsgrammatik och språkhandlingsteori}

Om vi i stället funderar över kopplingar mellan satsgrammatiken och språkhandlingsteorin, så händer lite andra saker. Något slags parallellitet finns det mellan satstyper (som hör till det satsgrammatiska systemet) å den ena sidan och de olika språkhandlingarna å den andra. Jag ger mig inte in i den omfattande diskussionen av olika sätt att förstå språkhandlingsbegreppet utan ansluter i detta sammanhang till Austins grundläggande distinktioner mellan lokution, illokution och perlokution. För (över)tydlighetens skull ger jag också hans förklaringar till begreppen. Att utföra en lokut handling är helt enkelt att säga något, eller med Austins egna ord: 'The act of 'saying something' [...] I call, i.e. dub, the performance of a locutionary act, and the study of utterances thus far and in this respect the study of locutions, or of the full units of speech." (Austin 1984: 94.) Att utföra en illokut handling är det vi åstadkommer genom att säga något.

To perform a locutionary act is in general, we may say, also eo ipso, to perform an illocutionary act, as I propose to call it. Thus in performing a locutionary act we shall also be performing such acts as:

asking or answering a question,

giving some information or an assurance or a warning, announcing a verdict or an intention,

pronouncing a sentence,

making an appointment or an appeal or a criticism, making an identification or giving a description,

And the numerous like. (Austin 1984: 98f.)

Yttrandens perlokuta kraft, slutligen, är nära förknippad med de båda tidigare diskuterade handlingstyperna, men avser själva effekten av den lokuta och den illokuta handlingen.

Austins grundläggande idé fördes vidare av Searle (1969), som drar upp riktlinjerna för en systematisk beskrivning av språkhandlingarna. Han laborerar dels med villkor på de språkliga, psykologiska och sociala omständigheterna som måste vara förhanden, dels med regler för hur 
man i enlighet med villkoren åstadkommer en viss typ av språkhandling (Searle 1969: 59ff). En utförlig och principiell diskussion förs om språkhandlingen 'löfte', och mer översiktligt redogörs för språkhandlingarna 'krav', 'hävdande', 'fråga', 'tack', 'råd', 'varning', 'hälsning' och 'gratulation' (1969: 66f). Det är alltså möjligt att på det här sättet uppnå stor träffsäkerhet $\mathrm{i}$ användningen av prototypiska konstruktioner. Beskrivningarna kan emellertid aldrig bli fullständiga. Andra uttryck än de prototypiska kan användas, och ett och samma uttryck kan användas för olika ändamål. Searle skriver att "it is important to realize that one and the same utterance may constitute the performance of several different illocutionary acts (1969: 70). En systembaserad beskrivning räcker alltså en bit på vägen, men mycket måste lämnas åt tolkning i den autentiska språksituationen.

Detta blir tydligt också i konkreta handboksbeskrivningar. I svenskan (liksom i många besläktade språk) kan man urskilja tre grundläggande satstyper, påståendesatser, frågor och imperativer. Till detta kan man lägga självständiga bisatser som kan fungera som optativer (om han bara kunde komma) eller exklamativer (att du kan bära dig åt på det viset). Dessa fem grammatiska/syntaktiska typer kan betecknas som prototypiska uttryck för några av de illokutioner som vi har att räkna med. Illokutionerna är emellertid väsentligt fler, som framgår av Austins formulering "and the numerous like" (se citatet ovan). Ett försök till en grundläggande klassificering ges i Jörgensen \& Svensson (1986:160ff). De urskiljer informerande, informationssökande, påverkande, känslouttryckande, performativa och aktualiserande språkhandlingar (i framställningen kallade talhandlingar). Man kan notera att de performativa språkhandlingarna, som ju var Austins utgångspunkt, inte har någon som helst prototypisk motsvarighet i det grammatiska systemet. Se också Teleman et al. (1999, bd. IV, sid. 680ff).

Skillnaderna mellan de grammatiska satstyperna och de språkhandlingsteoretiskt definierade illokutionära handlingarna motiverar också olika slags kvalificeringskriterier som analytikern (och på ett omedvetet plan också den vanlige språkbrukaren) utnyttjar i samband med det ena och det andra. För satsgrammatikens vidkommande är det alltså begreppet 'grammatikalitet' som är centralt, för textanalysens del är det 'koherens'; för språkhandlingsstrukturen är det 'lyckadhet' ('felicity"). 


\section{Jan Svensson}

De olika urskiljbara språkhandlingarna är alltså väsentligt fler än de tillgängliga sats- och meningstyperna, och vi måste alltså lämna den renodlade systembeskrivningen. Det finns inga sätt att avgöra vad som är en lyckad språkhandling annat än i en autentisk situation. Detta faktum är den viktigaste förklaringen till den något förvånande omständigheten att språkhandlingskategorierna är så underbestämda i förhållande till de grammatiska kategorierna. Språkhandlingskategorierna är framför allt pragmatiska kategorier, och som sådana kan de inte uttömmande beskrivas utan hänvisning till den diskursiva praktiken. Det är ju uppenbarligen också så att språkbrukarna inte har känt något trängande behov av att konventionalisera uttryck för särskilt många språkhandlingar. Den tolkningsfrihet som finns ger språkanvändningen den elasticitet som är nödvändig för att språket ska kunna vara ett smidigt redskap i kommunikationen. Hade varje enskild språkhandling varit kopplad till en specifik satstyp hade språkbrukarna blivit låsta på ett sätt som inte vore funktionellt. Likaväl som språkbrukaren har en grammatisk kompetens har hon vad man skulle kunna kalla en hermeneutisk kompetens. (Se dock nedan om konventionaliserade uttryck för språkhandlingarna utskällning och hot.)

Om detta resonemang är riktigt får det också konsekvenser för den professionella språkbeskrivningen. Det är enligt min mening meningsfullt att betrakta språket som om det vore ett system och göra beskrivningen av detta system så precis som möjligt. Men denna systembeskrivning har en gräns, där den systematiska generaliserande analysen måste ersättas av en tolkande och partikulär analys. I hanteringen av språkhandlingarna och deras illokutionära kraft verkar vi närma oss eller rentav överskrida denna gräns.

\section{Språkhandlingsteori och text}

Några centrala frågor som inställer sig vid jämförelsen av textperspektivet och språkhandlingsperspektivet är: Är text (uppfattat som en koherent sekvens av större omfattning än satsen) en språkhandling eller (enbart) en sekvens av språkhandlingar? Vilken är relationen mellan mikro- och makrohandlingar? Den första frågan kan man svara ganska entydigt på. En text kan betraktas som en språkhandling på något slags övergripande nivå, om man så vill på en makronivå. Detta hindrar givetvis inte att texten också kan ge uttryck för språkhandlingar på underordnade nivåer, om man så vill på mikronivå. Den andra frågan om relationerna mellan de olika nivåerna är betydligt svårare att svara på. 
Jag ska gripa mig an båda frågorna och en del andra som dyker upp längs vägen.

Redan i boken Text and Context från 1977 diskuterar Teun van Dijk handlingar och språkhandlingar i ett makroperspektiv. Han konstaterar att de flesta mänskliga handlingar har en global struktur och inbegriper handlingar som är sekventiellt och hierarkiskt ordnade visavi varandra. Att genomföra en resa kan betraktas som en handling på makroplanet men handlingen inbegriper en lång rad handlingar på mikroplanet som är nödvändiga för att makrohandlingen ska kunna genomföras. Man måste bestämma färdväg, köpa biljetter, boka sittplats, ta sig till stationen osv. Likadant förhåller det sig med språkhandlingar, som ofta måste planeras och tolkas på global nivå. Van Dijk (1977:238) ger ett konstruerat exempel som jag parafraserar här:

A. Hej?

B. Hej Peter, det är Jonte!

A. Nämen hej Jonte. Hur är det?

B. Fint. Jag skulle vilja fråga en sak. Har du fortfarande kvar Jennys gamla cykel, den där som hon inte använder längre?

A. Javisst. Hurså?

B. Jo, du förstår, vår Lisa fyller år i nästa vecka och hon behöver en cykel. Och jag tänkte att om Jenny inte använder sin längre, så kanske jag skulle kunna få köpa den och måla upp den och ge den till Lisa som födelsedagspresent.

A. Javisst, det går bra. Jag får väl fråga Jenny, men hon blir säkert bara glad för att kunna hjälpa till. När behöver du den?

B. Det var hyggligt av dig. Kan jag komma förbi i morgon? Och så kan du fråga Jenny?

A. Det blir bra. Vi ses i morgon.

B. Ja, hej då! Och tack ska du ha.

A. Hejdå.

I kommentaren till exemplet konstaterar van Dijk att sekvensen innehåller en lång rad olika språkhandlingar, som t.ex. hälsningar, frågor, påståenden, tack och förslag, men att man också kan se hela sekvensen som språkhandlingen förfrågan ("request"). Det går att analysera sek- 
vensen mer i detalj, vilket van Dijk också gör, men redan med det som sagts är den grundläggande poängen hemdriven. Språkhandlingar kan uttryckas på olika nivåer i en text, och texten som helhet kan uttrycka en språkhandling. Van Dijk menar att detta i själv verket är en nödvändig förutsättning för att vi ska kunna hantera någotsånär komplexa kommunikativa situationer. Han skriver: "The crucial fact is that the cognitive constraints on information processing, which require the formation of semantic macro-structures and which organize acts and speech acts in global units, at the same time have social implications: they determine how individuals wish, decide, intend and plan, execute and control, 'see' and understand their own and others' speaking and acting in the social context. Without them the individual would be lost in a myriad of detailed, incoherent pieces of visual, actional and propositional information." (van Dijk 1977:246.)

Den uppfattning som van Dijk ger uttryck för är alltså entydig. Samma uppfattning företräds av Brandt \& Rosengren (1991:6), som i flera stort upplagda projekt intresserade sig för frågan om samband mellan språk(system) och pragmatik: "Der Text ist nach unserem Modell als eine globale sprachliche Handlung zu betrachten. Mit einem Text wird also hier und jetzt sprachlich gehandelt." Brandt \& Rosengren urskiljer (liksom jag har gjort här) två nivåer i textstrukturen, nämligen "die grammatische und die pragmatische Ebene" (sid. 5). På den pragmatiska nivån räknar de med två viktiga dimensioner, handlingsstrukturen och informationsstrukturen, och i handlingsstrukturen, som står i fokus för deras diskussion, urskiljer de illokutionsstrukturen samt "die Sequenzierungsebene und die Formulierungsebene". Två av de förhållanden som Brandt \& Rosengren lyfter fram är särskilt viktiga. För det första att illokutionsstrukturen utgör en hierarki, med åtminstone en dominerande illokution som stöttas av en eller flera underordnade illokutioner (som antingen är komplementära eller subsidiära). För det andra att de olika nivåerna i handlingsstrukturen trots att de kan analyseras var för sig står i ett ömsesidigt beroende till varandra. (Brandt \& Rosengren 1991:43.) För att göra saken något konkretare ska jag återge några av de analyser som Brandt \& Rosengren redovisar. Deras material utgörs av olika typer av affärsbrev, och den överordnade illokution som de intresserar sig för är den direktiva. Deras första exempel är följande:

(1) Als Anlage übersenden wir Ihnen unser Schaltschema STA 220 in 6-facher Ausfertigung. Wir bitten Sie, uns nach Überprüfung 1 Exemplar mit Ihrem 


\section{Språket som hydra}

Genehmigungsvermerk versehen zurückzusenden. Wir hoffen, Ihnen hiermit gedient zu haben. (Brandt \& Rosengren 1991: 21.)

Av textens tre meningar utgör den andra textens huvudillokution. Den första meningen är komplementär och anger ett sakförhållande som är viktigt för förståelsen av kommunikationssituationen. Den tredje meningen är även den komplementär, men har vad Brandt \& Rosengren kallar kooperationssäkrande funktion.

I ett annat, likartat exempel förekommer också underordnade subsidiära illokutioner.

(2) Von unserer Vertretung $\mathrm{ABC}$ wurde Ihnen am 2.2.76 unter Plan Nr. XYZ vom 21.1. mit der Bitte um Genehmigung übersandt. Wir haben von Ihnen bis heute die Zustimmung nicht erhalten und es ist eine termingerechte Abwicklung des Auftrages nur mehr schwer durchzuführen. Wir bitten daher höflichst um ehebaldigste Genehmigung und Retournierung. (Brandt \& Rosengren 1991: 24.)

Här är det den sista meningen som bär huvudillokutionen (önskan). Den första meningen anger ett för förståelsen nödvändigt sakförhållande, medan den andra meningen dels anger ett sakförhållande, dels fungerar subsidiärt genom att motivera huvudillokutionen.

Genom analyser av det här slaget kan Brandt \& Rosengren redovisa texternas illokutionshierarkier. Den följande fasen i deras analysmodell avser sekventieringsnivån, där de intresserar sig för i vilken ordning de dominerande respektive de olika typerna av underordnade illokutioner uppträder. I de lite mer utvecklade exemplen kan de urskilja ett återkommande mönster som ser ut ungefär på följande sätt:

(3) Hinweise auf frühere Kommunikation - sachlicher Hintergrund - Grunde der Aufforderung - Aufforderung selbst - Folgen der erwünschten Handlung - ergänzende Sachverhaltsklärung - Kooperationssicherung (Brandt \& Rosengren 1991:36). 


\section{Jan Svensson}

Författarna anger inte explicit vilken grad av generalitet som denna kategorisering har, men man kan anta att det finns många i sig välformade brev som på olika sätt avviker från grundmönstret.

Den tredje och sista fasen avser formuleringsnivån, där det handlar om att beskriva vilka satsgrammatiska konstruktioner som används för att uttrycka den ena eller andra illokutionen. För de dominerande direktiverna gäller att de alltid uttrycks som huvudsatser (s. 39).

Innan jag går in på en mer detaljerad diskussion om hur en given texts illokutioner kan beskrivas vill jag kommentera den begreppsliga parallellitet som kan föreligga mellan enskilda språkhandlingar och hela texter. Det som ligger närmast till hands som en parallell till 'illokution' är begreppet 'funktion' (se Englund \& Svensson 2003). Som jag sade ovan kan ett yttrandes illokutionära kraft inte entydigt anges utan kunskap om den kommunikativa kontexten. Huruvida illokutionen är lyckad eller ej beror både av sändarens intention och av mottagarens tolkning och agerande. På motsvarande sätt är det med texters funktion. En text är välfungerande om den kan användas för det syfte i vilket den är tillkommen, antingen det handlar om att informera, roa, instruera eller något annat. Saken blir tydlig t.ex. i samband med instruerande texter. Ta till exempel ett matrecept. Vi kan inte avgöra huruvida funktionen uppnåtts förrän vi har kunnat studera användningen, dvs. om det faktiskt går att laga välsmakande mat utifrån den givna texten. Däremot är det möjligt att säga att en text är prototypiskt utformad för att bära en viss funktion - lika väl som enskilda yttranden prototypiskt kan bära viss illokutionär kraft.

Motsvarigheten till yttrandenas perlokutionära kraft är snarast det som brukar talas om som texters effekt. Perlokutionen/effekten har lägre grad av förutsägbarhet. Det är emellertid inte detsamma som att säga att perlokutionen/effekten är helt oförutsägbar. Den som skriver spänningsromaner - och gör det bra - är naturligtvis medveten om vilka språkliga och textuella grepp som har chans att ge den avsedda effekten.

Det finns alltså en tydlig parallellism mellan den enskilda språkhandlingen å ena sidan och den mer eller mindre utbyggda texten å den andra sidan. I båda fallen använder vi språket för att göra något, för att åstadkomma något i världen. Vi kan emellertid inte dra slutsatsen att de båda perspektiven är identiska. Det verkar finnas handlingar som bara kan 


\section{Språket som hydra}

uttryckas med enskilda satser, så t.ex. frågor och uppmaningar. Man kan förvisso tänka sig att en fråga underbyggs med ett antal påståenden som motiverar varför frågan ställs, men själva frågan måste bäras av en enskild språkhandling. Det är nog också så att somliga handlingar kräver hela texter för vissa handlingar ska vara uppfyllda. Om vi på allvar ska hävda att vi ger någon en instruktion krävs det sannolikt en text med någorlunda komplexitet. Vi skulle alltså ha en ordning där det finns ett mycket stort mått av överlappning mellan texters funktioner och enskilda satsers illokutionära kraft, men där överlappningen inte är total.

\section{Perspektivöverskridande analys}

Det råder alltså ingen tvekan om att texter (kortare eller längre) kan fungera som språkhandlingar, lika väl som enskilda satser kan göra det. Som har framgått har förhållandet länge varit uppmärksammat, och det finns också förslag på analysmodeller som kan användas. De texter som blivit föremål för analys är emellertid oftast strategiskt valda, vare sig de är konstruerade som i van Dijks exempel eller autentiska som i de exempel Brandt och Rosengren anför.

Så snart man lämnar de strategiskt valda texterna blir det uppenbart att analysen av sådana förhållanden som intresserar oss här, de olika textdelarnas relation till varandra, språkhandlingar som uttrycks i texten, textens olika betydelseskikt osv., inte kan genomföras mot bakgrund av någon på förhand uppställd modell eller med hjälp av något fast schema. Varje text med någon grad av komplexitet öppnar sig för olika slags tolkningar som lämnar utrymme för betraktaren och hennes val av perspektiv. Vi har därmed också obönhörligen lämnat den vetenskapliga plattform där vi med i någon mening objektiva metoder kan göra generella utsagor om vårt forskningsobjekt. I stället måste vi ansluta till de tolkande vetenskaperna, vilkas forskningsobjekt är partikulära och där kriterierna på vetenskaplighet måste formuleras i termer av intersubjektiv acceptans snarare än i utsagor om statistiska signifikanser eller $\mathrm{i}$ termer av falsifiering och verifiering.

I detta avsnitt ska jag illustrera vad som kan sägas om en text med oklar genretillhörighet och mer obestämt kommunikativt syfte. Jag kommer att aktualisera både satsgrammatiska fenomen, textaktiviteter, textfunktioner och illokutioner och därigenom åstadkomma kopplingar mellan grammatiska strukturer, språkhandlingar och textstrukturer. Jag vill diskutera vilka olika aspekter som måste hanteras för att visa på dessa 


\section{Jan Svensson}

kopplingar. Diskussionen genomförs som successiva delanalyser med åtföljande kommentarer.

Det analyserade textavsnittet är hämtat ur nationalekonomen Carl Hamiltons bok Absolut: historien om flaskan från 1994. Boken är i sin helhet en redogörelse för hur det gick till när den svenska vodkan Absolut introducerades i USA och gjordes till en gigantisk försäljningssuccé. Boken har alltså ett grundläggande förklarande och utredande syfte, men är samtidigt utformad som en berättelse med tydligt underhållningsvärde. Redan med detta val har författaren skapat ett komplext spel med olika typer av textaktiviteter och språkhandlingar. Det återgivna avsnittet syftar till att introducera en av bokens viktiga aktörer, Lars Lindmark, som under den aktuella perioden var chef för Vin- och spritcentralen, med ansvar för all alkoholförsäljning i Sverige. Det analyserade avsnittet behandlar en något tidigare period, då Lindmark rekryteras till finansdepartementet som budgetchef.

När Tv:n slog igenom i början av sextiotalet och statsministern kunde tala direkt till folket, var det första han sa till svenskarna att han hade RESURSER. De andra partierna pratade om sparsamhet och den kloka återhållsamheten och svenskarna satt lutade framåt i sina nymöblerade vardagsrum i sina nybyggda funkishus och stirrade in i de märkliga trälådorna, och de som inte hade någon egen apparat hade sprungit in till grannarna för att titta på deras nyköpta svartvita Philips och allihop fick de med egna öron höra statsministern säga att VI HAR RESURSER.

Men det stora socialdemokratiska partiet hade lagt sig till med den lilla egenheten att alltid vilja spendera litet mer än det hade gjort året innan. Och det kom sig av att varje minister i den socialdemokratiska ministären ansåg att just han måste ta ut lite mer än vad de andra gjorde. Ja, det var en tvingande nödvändighet, det hade inget med hans personliga åsikter att göra, problemen inom just hans område var bara så otroligt prioriterade.

Lindmark hade blivit tillsatt av Gunnar Emanuel Sträng, en cyklande landsvägsagitator som av en olyckshändelse blivit politiker och därefter regeringsmedlem och till slut finansminister, och någonstans i den processen hade Sträng surnat till. 
Surheten hade uppstått när Sträng fick hand om statens finanser och upptäckte att hans tidigare så kära kollegor i själva verket inte var vad han trodde, utan ett gäng snyltande storspenderare, den ene mer oansvarig än den andre, surheten hade tagit vägen över hans anletsuttryck, så att mungiporna nu pekade rakt neråt, sen hade den gått vidare in i hans karaktär, likt en gammal konjak satte den sig i väggarna och för vart år Sträng skötte sitt fögderi blev han allt surare. I mitten av sextiotalet hade finansministern arbetat upp en direkt avsky mot det besinningslösa slöseri som pågick runt omkring honom. Sparsamheten tycktes i lika hög grad påverka hans privata person. Han hade slutat köpa nya kläder och gick i lappat och lagat från fyrtiotalet. Han hade lagt sig till med både livrem och hängslen. Säkrade demonstrativt plånboken med en gummisnodd. Låste fickan med säkerhetsnål. Finansministern var numera så tvär att ingen kunde dra sig till minnes att gubben skrattat sedan omsättningsskatten infördes.

Sträng hade noterat hur Lindmark hanterade de snyltande ministrarna när de kom på besök med sina stora knäpportföljer, antagligen med baktanken att också plocka med sig några av finansens askfat. Sträng gillade vad han såg. Lindmark var visserligen inte utrustad med Strängs naturliga strävhet, Lindmark kunde till och med vara jovialisk, men det ursäktades av ett annat ädelt karaktärsdrag. Lindmark var en fullfjädrad koleriker.

I sin egenskap av budgetchef hade han en gång blivit ombedd att komma över till utrikesdepartementet för en dragning - "eftersom det var mer praktiskt", förklarade kabinettssekreteraren, än att diplomaterna promenerade till finansen. Eftersom det var mer praktiskt? De hade alltså ett ärende som de önskade föredra för honom, men tanken var att han skulle gå över till dem. Det hade svartnat för ögonen på Lindmark. Med darrande stämma hade han förklarat för kabinettssekreteraren att de nog hade missuppfattat finansdepartementets ställning i departementsorganisationen och nu jäklar gällde det för hans excellens utrikesministern att få på sig galoscherna illa kvickt och göra en fullkomlig tjurrusning över Gustav Adolfs torg om det inte skulle inträffa en svårartad olycka. 


\section{Jan Svensson}

Avsnittet består av fem stycken som fyller olika funktioner i texten. Det första stycket ger den allmänpolitiska och ekonomiska ramen för de händelser som ska beskrivas. Det tilltagande välståndet hade skapat möjligheter för politiska reformer som tidigare var otänkbara. Det andra stycket beskriver det dominerande socialdemokratiska partiets hantering av situationen och de frestelser som partiföreträdarna stod inför. I det tredje stycket, som också är det längsta, beskrivs den socialdemokratiske finansministern Gunnar Sträng, som i texten får personifiera motståndet mot de frestelser som partiet hade att hantera. Författaren låter Strängs ekonomiska/politiska uppfattningar smälta samman med hans personlighet. I det fjärde stycket får vi förklaringen till att Sträng ville rekrytera Lindmark till finansdepartementet. De var i mångt och mycket samma andas barn. I det femte och sista stycket ges sedan ett roande exempel på Lindmarks koleriska personlighet.

En sådan inledande grov analys av texten bör vara tämligen okontroversiell. Den kan utföras utan någon teknisk apparat, och det är troligt att de flesta läsare skulle göra ungefär samma överväganden. Däremot kan denna första analysskiss inte relateras till något eller några generella mönster för hur man bygger upp texter. Texten är ett resultat av författarens självständiga kreativa val. Texten kan inte heller pressas in i någon genrefålla.

Det är inte heller så lätt att nagla fast enskilda textaktiviteter/sekvensprototyper. Den övergripande textaktiviteten är berättelse (eller narration); det gäller för boken i sin helhet, och också för detta avsnitt. Vissa delar, i synnerhet avsnittet om Sträng hade kunnat vara hämtat ur en roman. Om vi söker språkhandlingar på den överordnade nivån i textutdraget kan vi säga att texten introducerar en av de viktiga personerna. (Lindmark är nämnd tidigare, men inte närmare presenterad.) Samtidigt hjälper texten till att förklara varför Lindmark uppfattades som lämpad för det jobb han fick. Begreppen 'introduktion' och 'förklaring' skulle kunna användas både för att beteckna språkhandlingar och textaktiviteter. Detta kan antingen ses som en fördel, då olika skikt av analysen samspelar, eller som en nackdel, eftersom vi får en besvärande överlappning.

Om vi lite mer närsynt granskar de olika styckena var för sig kan bilden både kompliceras och nyanseras. 


\section{Språket som hydra}

Det första stycket är alltså en bakgrundsberättelse, där författaren ger ramen för det som följer. Till stora delar för han ordet själv, men det förekommer också exempel på det som i den diskursanalytiska traditionen kallas representerad diskurs. Statsministern får komma till tals vid två tillfällen och "de andra partierna" blir också refererade, om än på ett mer indirekt sätt. Förekomsten av representerad diskurs illustrerar ett fenomen som man inte kommer förbi, då man försöker nagla fast språkhandlingar och textaktiviteter, nämligen att texter ofta drivs framåt på flera nivåer, vilket gör att olika delar av texten ramas in i varandra (se t.ex. Ledin 1995). I de delar där författaren själv för ordet har vi att göra med en renodlad berättelse, men i de korta sekvenser där statsministern får ordet är det frågan om andra språkhandlingar. Innehållet är detsamma vid båda tillfällena, men de grammatiska resurserna utnyttjas av författaren på lite olika sätt. Den första sekvensen är en fullkomligt konventionell indirekt anföring, med anpassning av tempus och deixis. Den andra sekvensen däremot företer en blandning av indirekt och direkt anföring. Effekten blir ökad intensitet, vilket ytterligare förstärks av användningen av versaler. Den språkhandling som representeras i de båda anföringskonstruktionerna är inte en berättelse, det är en utsaga, men det är också ett löfte, ett löfte till svenska folket att den politiska makten ska kunna göra tillvaron bättre för medborgarna.

Det kan finnas skäl att kommentera författarens användning av de grammatiska resurserna också i ett annat avseende, nämligen hans sätt att utnyttja interpunktionen. Stycket består av två grafiska meningar, som tillsammans innehåller 91 ord, vilket kunde tyda på en komplex meningsstruktur. Så är det emellertid inte, eftersom den andra grafiska meningen består av fyra syntaktiska meningar (makrosyntagmer), i ett fall åtskilda av kommatecken. Den effekt som författaren åstadkommer är snarast ett slags forcerad framställning. Berättaren har så mycket att säga att han inte riktigt hinner hejda sig.

De analytiska kommentarer som jag har gjort här kan till en del hänföras till en analys som bygger på objektiv metodik. Givet en konventionell och allmänt omfattad grammatisk apparat med verktyg för att diskutera meningsstruktur, interpunktion och anföringstekniker skulle nog varje läsare komma till samma resultat. De kommentarer som avser språkhandlingar och textuella effekter av de språkliga valen är emellertid inte sådana. De förutsätter en tolkning som i sin tur bygger på 


\section{Jan Svensson}

allmän språkförmåga och erfarenhet av hur olika uttrycksformer brukar fungera (dvs. det som jag ovan talade om som en hermeneutisk kompetens).

Det tredje stycket har en i flera avseenden svävande karaktär. Berättelsen fortsätter med ett slags personifiering av partiet, men det finns också ett tydligt inslag av förklaring eller explikation. Författaren är helt explicit och använder en konventionaliserad konstruktion ("det kom sig av") för att tydliggöra relationen mellan det första tankeledet (egenheten att vilja spendera) och det andra (att varje område var särskilt prioriterat). Också i detta stycke lägger författaren över ordet till andra aktörer. Det sker dels med en konventionell indirekt anföring styrd av tänkeverbet ansåg, dels med en konstruktion som närmast är att beskriva som fri indirekt anföring eller erlebte Rede, ett grepp som är vanligt i många typer av skönlitterära framställningar, men som är sällsynt i sakprosaframställningar. Den textuella effekten är snarast en ökad känsla av närvaro. Man kan fundera över alternativen. I direkt anföring borde det sett ut ungefär så här:

(4) Det är en tvingande nödvändighet, det har inget med mina personliga åsikter att göra, problemen inom mitt område är bara så otroligt prioriterade.

Men detta alternativ är närmast uteslutet i den aktuella texten. Det skulle förutsätta att en specifikt definierad person (minister) hade uttalat sekvensen vid något specifikt tillfälle - och så är ju inte fallet. Det handlar i stället om att återge en allmänt spridd hållning. I indirekt anföring hade författaren fått skriva ungefär så här:

(5) Ja, var och en ansåg att det var en tvingande nödvändighet, som inte hade med den enskilde ministerns personliga åsikter att göra utan som berodde på att problemen inom hans område var prioriterade.

Detta hade varit ett möjligt alternativ, men det är lätt att se att det av författaren valda alternativet skapar en mer livfull och engagerande framställning.

Oberoende av vilken effekt den valda framställningsformen ger, så ligger det i den representerade diskursen en förklaring på lägre nivå. Även här finns det två tankeled som förbinds av ett mer eller mindre 


\section{Språket som hydra}

konventionaliserat uttryck. Det första tankeledet (jag måste ta ut lite mer) förbinds med det andra (problemen är prioriterade) med hjälp av uttrycket "tvingande nödvändighet". Språkhandlingarna och textaktiviteterna måste alltså friläggas på sina respektive nivåer. Författarens förklaring till utvecklingen inom det socialdemokratiska partiet bygger på den förklaring som ministrarna anför för att få mer pengar.

I det tredje stycket närmar sig författaren föremålet för framställningen, alltså Lars Lindmark, men han gör det med en utvikning om finansministern Gunnar Sträng. Stycket är i sin helhet en personbeskrivning, men det intressanta är att den helt dominerande andelen av de använda verben är dynamiska (ca 20), endast några få är statiska (två fall av vara samt uttrycket pekade neråt). Sträng introduceras oerhört effektivt i en apposition, där författaren på en enda rad ger en miniatyrbeskrivning av hans karriär. Omedelbart därefter serveras huvudpoängen för läsaren: "och någonstans i den processen hade Sträng surnat till". I det här stycket släpper författaren inte ordet ifrån sig, möjligen med undantag för uttryck som "snyltande storspenderare", "oansvarig" och "besinningslösa raseri”, som vi kan anta beskriver Strängs perspektiv mer än författarens. Det finns emellertid inga språkliga signaler för detta perspektivbyte.

Det finns mer att säga, men den viktiga poängen är att vi alltså får en kollision mellan de språkliga uttrycksmedel som används och den textaktivitet (och eventuellt den språkhandling) som för varje läsare framstår som den dominerande, nämligen beskrivningen. Detta är inte problematiskt för texten, men det är problematiskt för den som vill ge en generell redogörelse för hur man utför textaktiviteten beskrivning. Återigen ställer författarens kreativa förhållningssätt modellerna på ända.

I det fjärde stycket är turen så slutligen kommen till Lindmark, som beskrivs som en person som förstår att hantera anspråksfulla kolleger. Han kan vara jovialisk men är samtidigt kolerisk. Denna beskrivning ligger emellertid inte entydigt i författarens mun; här är det mer entydigt Strängs perspektiv som råder. Som en allvetande berättare kan författaren återge vad Sträng noterar och vad han gillar. Även här blir en schematisk språkhandlingsanalys besvärlig.

I det femte och sista stycket relaterar författaren en episod, som ytterligare belyser Lindmarks karaktär. Stycket inleds på ett sätt som är typiskt 


\section{Jan Svensson}

för anekdoter: "I sin egenskap av budgetchef hade han en gång blivit ombedd att komma över till utrikesdepartementet för en dragning". Sedan kunde man ha tänkt sig att författaren behöll ordet och berättade vidare, men så sker inte, utan han bollar över ordet till en av de inblandade som i blandad anföring får förklara att den föreslagna ordningen vore den mest praktiska. Därefter får vi plötsligt höra Lindmarks röst i en form som närmast får beskrivas som erlebte Rede. Effekten är densamma som i andra stycket, med ökad närhet, men dessutom kan författaren på det här sättet mycket effektivt gestalta Lindmarks undertryckta vrede. Användningen av pluskvamperfekt i de följande meningarna skapar samtidigt en distans mellan författaren - som bara hört detta berättas - och den återgivna handlingen. I dessa båda meningar har författaren inledningsvis ordet, men i den sista långa meningen lägger han över det till Lindmark, först i indirekt anföring och därefter ännu en gång i erlebte Rede. Här läggs åtminstone tre olika språkhandlingar i Lindmarks mun, först en utskällning (att de nog hade missuppfattat finansdepartementets ställning), sedan en uppmaning (få på galoscherna illa kvickt) och slutligen ett hot (om det inte skulle inträffa en olycka).

Att dessa tre språkhandlingar är förhanden går naturligtvis inte att leda $\mathrm{i}$ bevis på något entydigt sätt. Utsagan är beroende av min tolkning av textpartiet. Denna tolkning är emellertid inte helt frikopplad från de lexikala och syntaktiska realiteterna. Adverbet nog i det första fallet är en kraftfull signal för att det faktiskt är frågan om en utskällning. Om adverbet utelämnas kan meningen uppfattas som ett mer neutralt påstående. I det andra fallet används ju faktiskt en uppmaningskonstruktion, som förstärks av det fasta uttrycket illa kvickt, som knappast kan användas i andra konstruktioner. Och i det tredje fallet används en negerad konditionalsbisats på ett sätt som närmast är en konventionaliserad hotelse. Tolkningen styrs av de valda språkliga uttrycken och deras respektive språkliga kontext, men dessa språkliga uttryck kan inte bilda utgångspunkt för en systembeskrivning.

Det återgivna avsnittet visar vilken komplicerad materia vi har att göra med då vi vill diskutera förekomsten av språkhandlingar i texter som inte är endimensionella eller tillrättalagda. Hamiltons text är inte svår, den kan snarare betecknas som lättläst. Den är informativ och den drivs framåt i snabbt tempo. Den låter sig emellertid inte enkelt analyseras med hänvisning till schematiska modeller för hur texter byggs upp och på vilket sätt de låter språkhandlingarna framträda. Detta förhållande är 


\section{Språket som hydra}

emellertid inget argument mot tanken att texter i sin helhet kan utgöra språkhandlingar och att det kan finnas underliggande språkhandlingar på olika nivåer. Däremot är - menar jag - förhållandet ett argument mot att språkhandlingskategorierna på ett mer påtagligt sätt ska kunna integreras i den generella systembeskrivningen (för ett enskilt språk eller för det mänskliga språket).

\section{Avslutande kommentarer}

Vad blir det då av allt detta? Ja, kanske det stannar vid den föga originella insikten att språket är ett så komplicerat fenomen att det inte låter sig fångas i en enhetlig beskrivning. Däremot kan vi komma en bit på vägen om vi väljer ett specifikt perspektiv och låter detta perspektiv vara vägledande för analysen och beskrivningen. Jag har behandlat tre sådana perspektiv här, ett satsgrammatiskt perspektiv, ett textperspektiv och ett språkhandlingsperspektiv, och jag har sökt likheter och skillnader mellan dem i akt och mening att diskutera de olika perspektivens förutsättningar.

Ett fenomen som både förenar och skiljer är förekomsten av kvalificeringskriterier, alltså grammatikalitet, koherens respektive "lyckadhet". Det faktum att kvalificeringskriterier kan ställas upp är ett indicium på att vart och ett av perspektiven har något slags (mental) realitet. Denna realitet gäller för språkvetare (vilket inte är så förvånande), men det gäller också för "vanliga" språkbrukare. Man kan lätt tänka sig repliker och replikskiften som "Så kan man väl inte säga", "Du pratar/skriver ju helt osammanhängande" och "Du lovade att komma" - "Nej, det gjorde jag inte alls". Att vi överhuvudtaget kan tänka oss sådana repliker visar att vi har anledning att ta perspektiven på allvar. Det faktum att vi behöver tre olika slags kvalificeringskriterier visar emellertid lika tydligt att vi har att göra med tre olika fenomen, som inte utan vidare kan integreras.

Vad gäller de tre perspektivens relation till dikotomin system vs bruk är det ingen tvekan om att det satsgrammatiska perspektivet är det som i första hand låter sig förenas med en systembaserad beskrivning. Inom den satsgrammatiska ramen (oberoende av beskrivningsmodell) kan man komma mycket långt på vägen mot en generell systematisk beskrivning. Det kommer alltid att finnas marginella konstruktioner, som inte låter sig beskrivas i botten och vilkas grammatikalitet kommer att 


\section{Jan Svensson}

vara omdiskuterad, men det är ändå frågan om undantag. Detta gäller inte för det textuella perspektivet, som intar ett slags mellanläge. Det går att peka ut språkliga enheter, med vars hjälp man kan skapa eller förtydliga samband mellan satser, men det går inte att formulera generella principer för hur texter ska beskrivas (se dock resonemanget om starkt konventionaliserade genrer). Möjligheterna till generell systematisk beskrivning av språkhandlingarna (uttryckta i enskilda yttranden) är också mycket begränsade. Det finns några få konstruktionstyper som så att säga är reserverade för vissa språkhandlingar, men vad det språkliga yttrandet faktiskt åstadkommer är mycket hårt bestämt av den speciella situation där yttrandet fälls. Dessutom kan de prototypiskt entydiga språkhandlingarna ofta laddas med annan illokutionär kraft än den prototypiska.

Ett annat och ännu mer förenklat sätt att uttrycka förhållandet är att säga att satsgrammatiken drar starkt åt systemhållet, textbeskrivningen intar en mellanposition, och beskrivningen av språkhandlingar drar starkt åt brukshållet. Förhållandet skulle kunna illustreras som i följande modell.

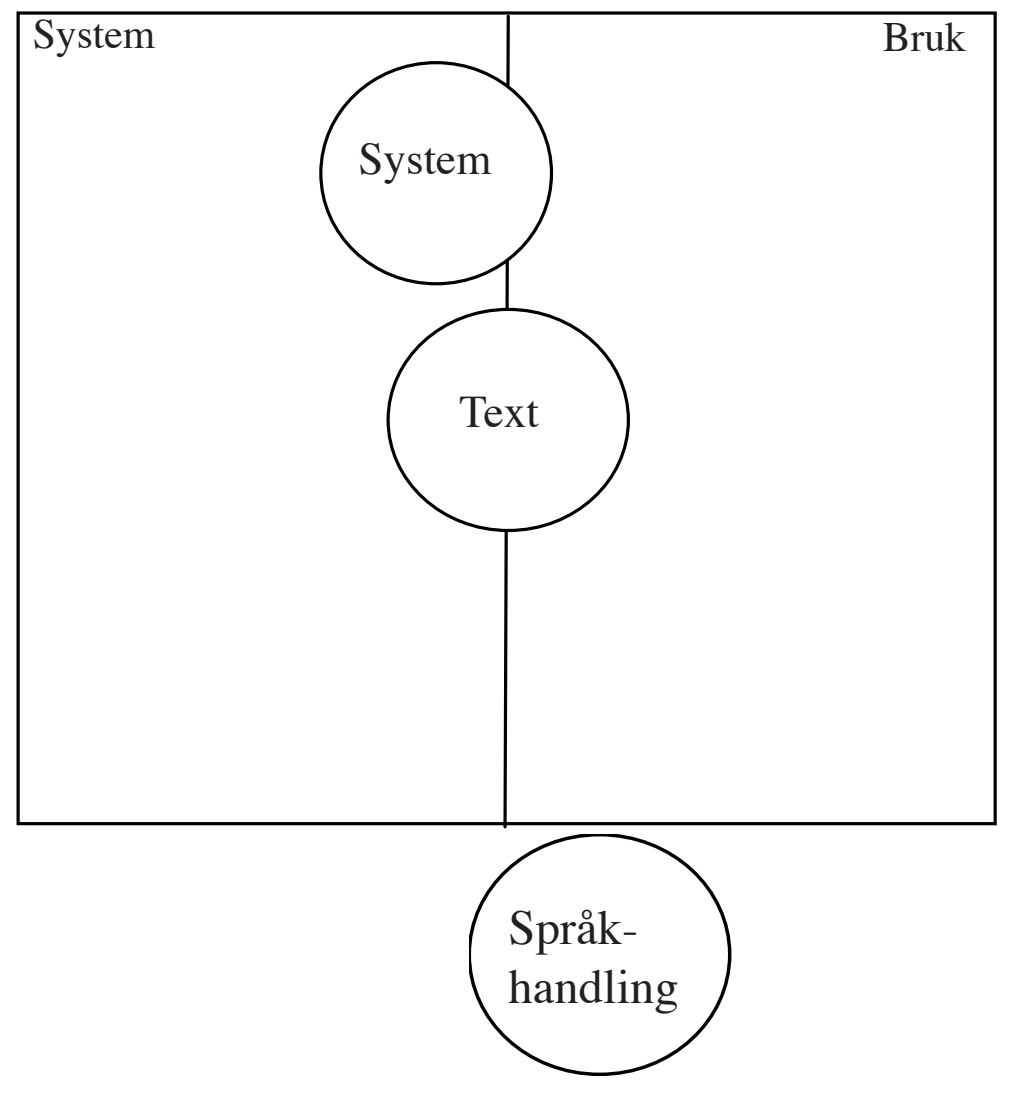




\section{Språket som hydra}

Det påstående som görs med hjälp av modellen är inte bara ett trivialt påpekande om att de tre språkvetenskapliga perspektiven är olika i största allmänhet. Det är också ett påstående om att vi har att göra med verksamheter som från vetenskapsteoretiska utgångspunkter är väsensskilda. Systembeskrivningarna har, som framgick av inledningen, generalitetsanspråk, och oberoende av vilken beskrivningsmodell som används kan ambitionen beskrivas som nomologisk. Bruksbeskrivningarna är tolkande och partikulära och kan beskrivas som ideografiska. Att vi har att göra med ganska olikartade vetenskapstyper medför också de olika perspektiven aktualiserar helt olika metodologier. Det är mot denna bakgrund kanske inte så konstigt att textforskningen, som står med ett ben i varje läger, ibland kan upplevas som lite vacklande och vilsekommen.

När det gäller relationen mellan språkhandlingar och deras illokutioner å ena sidan och texter och deras funktioner å den andra sidan kan man konstatera att det råder stor men inte total överlappning. I en strävan att skapa ett enhetligare beskrivningssystem kunde det vara frestande att använda en och samma terminologi för att hantera båda fenomenen. Det låter sig dock inte göra utan att samtidigt göra våld på empirin. Det finns språkhandlingar som kan uttryckas i enskilda satser men inte i texter, och det finns andra, som förutsätter texter för att kunna uttryckas.

För att få ordning på begreppet 'text' behöver man nog också laborera med begreppen 'genre', 'textaktivitet' och 'processtyp'. Med ett välfungerande genrebegrepp skulle det vara möjligt att beskriva en del generaliseringar om texters uppbyggnad, som i vissa avseenden skulle kunna parallelliseras med uppbyggnaden av satsen - dvs. man skulle kunna göra partiella systembeskrivningar. Detta förutsätter dock en på motsvarande sätt välfungerande arsenal av textaktivitetskategorier, vilka i sin tur borde vara uppbyggda av generaliserade processtyper. Tendenser till detta finns i litteraturen, men inte som mycket mer än just tendenser.

Det kan alltså tyckas som om rubrikens allusion till den grekiska mytologin inte är alldeles orimlig. Alla vi som sysslar med språkforskning har på ett eller annat sätt en ambition att betvinga språket och få det att passa in i våra beskrivningsmodeller. Men så fort vi får ordning på ett problem så dyker det upp två nya. Det är lite frustrerande, men det är nog också det som gör språkforskningen till den fascinerande verksamhet den är. 


\section{Jan Svensson}

\section{Litteratur}

Adam, Jean-Michel (1992). Les textes: types et prototypes. Paris: Édition Nathan.

Asdal, Kristin m.fl. (2008). Tekst og historie. A lese tekster historisk. Oslo: Universitetsforlaget.

Austin, J.L. (1984/1962). How to do things with words. Oxford: Oxford University Press.

Brandt, Margareta \& Rosengren, Inger (1991). Zur Handlungsstruktur des Textes. Sprache und Pragmatik 24. Lund: Germanistiches Institut.

Dijk, Teun A. van (1972). Some aspects of text grammars: a study in theoretical linguistics and poetics. The Hague: Mouton.

Dijk, Teun A. van (1977). Text and Context. Explorations in the semantics and pragmatics of discourse. London: Longman.

Englund, Boel \& Svensson, Jan (2003). Sakprosa och samhälle. I: Englund \& Ledin (red.) Teoretiska perspektiv på sakprosa. Lund: Studentlitteratur.

Fairclough, Norman (1992). Discourse and social change. Cambridge: Polity Press.

Gregersen, Frans (2006). Strukturalismen i vore hjerter. Nydanske sprogstudier 34-35.

Hamilton, Carl (1994). Absolut: historien om flaskan. Stockholm: Norstedts.

Jörgensen, Nils \& Svensson, Jan (1986). Nusvensk grammatik. Malmö: Gleerups.

Jörgensen, Nils (1976). Meningsbyggnaden i talad svenska. Lundastudier i nordisk språkvetenskap, serie C, nr. 7. Lund: Studentlitteratur.

Ledin, Per \& Selander, Staffan (2003). Institution, text och genre. I: Englund \& Ledin (red.) Teoretiska perspektiv på sakprosa. Lund: Studentlitteratur.

Ledin, Per (1995). Arbetarnes är denna tidning: textförändringar i den tidiga socialdemokratiska pressen. Stockholm Studies in Scandinavian Philology, New Series 20. Stockholm: Almqvist \& Wiksell International.

Ledin, Per (2000). Veckopressens historia. Del II. Svensk sakprosa nr 29. Lund: Institutionen för nordiska språk. 


\section{Språket som hydra}

Martin, J.R. \& Rose, David (2008). Genre Relations, Mapping Culture. London: Equinox.

Nord, Andreas (2008). Trädgårdsboken som text 1643-2005. Stockholm Studies in Scandinavian Philology. New Series 47. Stockholms universitet: Nordiska språk.

Sandahl, Dag (u.u.). Die Wiedergabe der Wirklichkeit. Lunds universitet: Språk- och litteraturcentrum.

Searle, John (1969). Speech Acts. An essay in the philosophy of language. Cambridge University Press.

Svensson, Jan (2005). Att bedriva historisk textforskning. Några teoretiska reflexioner. I: Falk \& Delsing (red.), Studier i svensk språkhistoria 8. Lunds universitet: Institutionen för nordiska språk.

Teleman, U, Hellberg, S \& Andersson, E (1999). Svenska Akademiens grammatik. Stockholm: Norstedts.

Wendt, Bo A. (2009), Text som mängd eller helhet - och i verkligheten. Om en språkvetares textbegrepp. Text, svensk Tidskrift för Bibliografi, vol. 7.

Jan Svensson

Professor i svenska språket

Lunds universitet

Språk- och litteraturcentrum

jan.svensson@nordlund.lu.se 